\title{
Concept of Human and Nature in Kazakh Poetry
}

\author{
Akbota Abiyr $^{1} \&$ Perizat Berikbolova ${ }^{1}$ \\ ${ }^{1}$ Faculty of Philology and Educational Sciences, Suleyman Demirel University, Kaskelen, Kazakhstan \\ Correspondence: Akbota Abiyr, Suleyman Demirel University, 1/1 Abylaikhan Street, Kaskelen, 040900, Almaty \\ Province, Kazakhstan. Tel: 11-70-1953-5700. E-mail: abiyr@mail.ru
}

Received: July 22, 2014 Accepted: September 9, 2014 Online Published: October 30, 2014

doi:10.5539/ass.v10n22p280 URL: http://dx.doi.org/10.5539/ass.v10n22p280

\begin{abstract}
Since the early age, the human has been attempting to understand the mysteries of life and to find the answer to the eternal question through interaction with the surrounding nature. It was the original decision of the human to attempt discovering the many secrets of the elemental forces occupying the enormous environment, which he feared. The first teacher of the human was the nature, and the first thing it taught the human was the ability to perceive.

In the XXI century, a young generation of poets came in who continued to pursue what their seniors had begun and were able to give it a new breath and dynamic energy. In lyrics, it takes great poetical perception to amalgamate the human and the nature and describe them beautifully by way of antithesis.
\end{abstract}

Keywords: figurative pattern, lyrical character, lyrics, mythological thinking, poetry

\section{Introduction}

The nature poetry has developed depending on each nation's beliefs, lifestyle and everyday life. The society may change, the history may change, but the nature will always remain in the same infant, innocent, cloistral state. The nature is common, but the perception is always different.

In the written Kazakh poetry, Abai's oeuvre is the standard of psychologic parallelism, nature portrayal. Such pieces of poetry as S. Seifullin's Kokshetau, I. Zhansugurov's Zhetisu Suretteri (Zhetisu Scenes), modern poet F. Ongharsynova's Kuzdin Songy Kunderi (Last Days of Autumn), K. Akhmetova's Aghashtar (Trees) penetrate the Kazakh readers' minds, blend into their objective reality, and coalesce into nature.

In the modern Kazakh poetry, the poetry of nature is in its renaissance period. Depiction of the nature passed through the prism of feelings in comparison with the specifics of human's nature, its presentation through good and bad deeds of human, and demonstration on the personal level are being actively mastered in today's poetry of youth.

Barky smoke arm's doing its muscle-flexing,

Greyish sky's so dark midday and it's so vexing.

Whitebeard Mountain's got a cold and is sneezing,

And the sombre fog is even more suppressing.

(Askerbekqyzy, 2008)

Dolour must be eye's "abyss"

It will make the Moon go yawl.

(Anthology of young poets' writings,2000)

The wind is bravely scampering around the foot,

The clever mother Earth is lying mute.

Like a baibishe (Note 1) wrapped up in a white cloth,

The steppe lies as if clad in a white snow suit.

(Sarybai, 2007) 
According to A. Blok, "That who spots the lines ordinary people's eyes cannot get a sight of, and whose mind penetrates deeply into and feels the nature's secrets behind the outer surface thereof, is a real word painter" (Askerbekqyzy, 2008). In the above verses, we particularly note an exceptional sensitivity in feeling the seasonal scenes and mastery in turning such feelings into characters. In the process of depicting certain season, the poet not only cognizes the nature but also adapts it to his own world and passes it through himself. Let us turn our attention to the character of Moon in the lyrical poetry of nature as written by poet Almas Temirbai. The poet interweaves the nature with Almas's own mood, musings and dolour, i.e. the theme's framework is the character of a man, and it's unveiled and developed through the aid of such symbolic as the natural elements, mainly the moon, the sun, or the night.

\section{Discussion}

In a mythical mind typical for the era of mythological thinking, the entire nature is perceived as a living, conscious spirit. The belief that holds the human and the nature to be equal and that the nature has all the feelings and states of mind that the human has such as thinking, mourning, rejoicing is known to be the basis for figurative, allegorical, inkling meanings in the imaginative thinking system. The subject of our consideration, the moon, is also one of the natural phenomena, namely one of its instants, moments. In the poet's work entitled Peshene (Note 2) the underlying motive is the human's whispering with his own thoughts and arguing against the outside world's facts, and coming with the answer to the rhetorical question of "Should I escape Myself or should I escape the Life?" in the form of the Other (the "Other" here is another man, society) and the Death. General answer in the poem is given in the following verses: "If I run away for light, Where am I supposed to go?! Earth is just a huge graveyard, With the Moon atop although,"-and the character of the Moon play the role of the poem's attribute. In the poem, the Moon is a thing character; however, in poetical terms it has the attribute of the earth's light, or torch.

It is worth noting that the Moon related characters are used quite frequently in the modern poetry. The Moon is perceived as a lyrical subject. Of course, in the first place the Moon is, in the real life, a celestial object that can be seen at night, glow, reflect light, and change its form and phase. Conceptual meanings of the Moon are:

- it is an existing object that can feel the emotions attributed to the human;

- it relates to the movement of time;

- it is contrary to the Sun.

In the interpretational meaning, the Moon has emotional and aesthetical components. In terms of emotional concept, the Moon negatively affects the spirits of a lyrical subject. Dominating emotions of the Moon include dolour, sorrow, solitude, stress, hopelessness, heartache. Some real-life things are cognized through emotional, affective moods, internal feelings in the human mind.

In terms of the aesthetical concept, the Moon actively participates in and contributes to the emotional description in the imaginative cognition. The Moon's rays, light, secrecy, mystery, beauty are especially descriptive as the aesthetical category. In the writings by Maraltai Raiymbekuly, the Moon apparently exerts a special influence on the poet's mood.

When the Moon was full, into mischief I ran,

Grieving is my heart, and I was left alone.

See it from the waves on the full Moon,

I am breathing fire into air.

Don't you keep yourself aloof, my shining Moon?

Please come out and let me shelter your bright light.

There was a swan-like girl, so beautiful,

But she must have flown away, what can I do?! (Issadil, 2012)

In an impulse to the Moon,

I entrusted secret my,

Stars have also drawn a sigh,

And called my secret "lonesome."

Feel with us, the old Moon, 
Favour us, the young Moon.

Let the sunset be always red,

Let the sunrise be always bright. (Temirbai, 2008)

In the national being of the Kazakhs, it is a well-known pre-Islamic tradition to converse, to talk with the Moon through greeting every young Moon, i.e. saluting a safe arrival from one Moon to another. The Moon is a symbol of our Islamic custom. It is no coincidence that the poets have in their writings prayers devoted to the Moon.

The character of the Moon that is frequently encountered in the Kazakh poetry takes its origin in the national traditions. Starting from the ancient beliefs and worshiping Tengri through more recent adoption of Islam, the character of the Moon continues to be a special totem. The human have worshiped the Moon and created a whole system of beliefs about it. The Turkic peoples have never kept aloof of the nature and have always perceived it as a whole. Turkic people in 'Kultegin' and other runic monuments entrusted the following 'I inspired on the eternal stone everything. I wanted to say. Having looked at it is aware of that. Everything is written all around the stone. ' (Monuments, 2001) They have strengthened their beliefs by forming a deific, mystical, faith tradition through such religious practices as worshiping and deifying the sky, earth, moon, fire, water. One of the named objects is the Moon. A tradition has developed to believe in the Moon, to worship it, to make wishes and offer prayers through the Moon. Secondly, the Moon has turned in the human minds into a good omen as a reference object that delivers from the evil of the night, protects against the dark, and beacons the strayed. As Almas says in his The Moon in support of the foregoing:

Bismillahi, bismillahi... Go to sleep,

Go to sleep and sleep you tight and sleep you deep.

In the morning, so excited like full Moon,

Break my whole new day in a bright peep-(Temirbai, 2008)

the poet offers a beautiful picture of the Moon in reply to his young daughter's request before going to sleep: "Daddy, can you please bring me the moon?" In the following verses, he uses very skilfully the entire understanding and beliefs accumulated during centuries in his Kazakh mind.

So you told me: "Daddy, I'll support,

Bring it, please, I want to play with it."

But the Moon is the forefathers' life-long dream,

And, my dear, the dream may not be played with! .. (Temirbai, 2008)

By concluding his poem with the following words: "Now, my sweet child, go to sleep, and you'll see in your dream your father bringing you the moon," Almas is seen as an aqsaqal (Note 3) giving his blessing to a little child, and through this image one can trace the similarity between the moon and the human. While worshiping a thing or phenomenon or existence is scientifically referred to as the "fetishism," Almas has beautifully depicted it poetically. In the modern Kazakh poetry, the character of the Moon has become a wholly typical character and takes a special place in the poetry of youth. The poets take the Moon for a human and, as poets, share their secrets and dolour with it.

I have roamed a lot in sorrow in a big town,

Much to Moon's delight that smiled at me

(Issadil, 2012)

Moon moves not, it's at rest,

Who can cry when short of breath? .. (Askerbekqyzy, 2001)

See it from the waves on the full Moon,

I am breathing fire into air.

(Raiymbekuly, 2001)

The personification method has been used in the lyrical poetry in a range of its varieties and aspects. One can even say that this method takes the leading place in depicting and describing the human's mood, emotions and feelings at every moment, and his rejoice and dolour through natural phenomena. All of the nature's things and phenomena such as the moon and sun, wind, night, river, flower and so on, are reflected and depicted in the imaginative thinking by replacing them with the deeds attributed to the human, and by comparing and twinning 
the same with them. And it is logical to search for the links of such applications in the imaginative thinking patterns coeval to the mythological thinking and human mind growth in the era when the ancient world view or, in other words, mythological mind dominated. Personification is the only way of unveiling a lyrical character's being. One can find a lot of such personifications reborn, revitalised in the modern Kazakh poetry. When we talk about personification, the first thing that needs to be discussed is the depiction of the natural phenomena and things, and in the poetical language the sky, clouds, night, wind etc. are described through human deeds. It is true that poetical decoration of the changes of mood, bittersweet feelings requires of the poet not only his mastery but also sensitiveness and keen perception. And when we talk about creation of beautiful patterns and the masterful painting in our modern lyrical poetry, the first name that comes to mind is that of a young generation representative, Maraltai Raiymbekuly. An example from his writings:

When the Sun rose from horizon it was upset,

And into my heart an anxious feeling's crept.

If a hand is extended to the lonely heart thereat

A finger is a blessing ray on it, as it felt. (Anthology of young poets' writings, 2000)

Just a moment of the nature's picture. But, while the poet expresses his own mood through "upset sun," a sudden picture of word expressed in "extended hand" and "finger being a blessing ray" can be regarded as attributes of our national poetry's power of imagination. Generally, the poet is prone to closely interact with the nature and to make it talk. His writings full of such personification demonstrate the poet's mastery in describing everything in the world of feelings through the nature's phenomena.

In the poet's writings, every single thing, every phenomenon is in focus and is involved in the poetical turn of speech. One of them is the Moon. And if the Moon is the fruit of the mythological era, mythical mind, Maraltai's poems are the works that were born of an imaginative thinking.

Depiction of the Moon in a poetical personification manifests in various ways in Maraltai's lyrical poetry. N. Orazalin prefaced M. Raiymbekuly's The Moon book of poems with the following words: "Poet Maraltai is close to dolour, woe, dark tones. Some may not like it. As to me, I don't think it to be a shortcoming. A pen that has never seen the ink of sorrow and dolour can produce nothing that is based on the bitter truth of life... So, if Maraltai is to prepare for tomorrow's peaks and summits, he needs to explore the breadth and depth of poetry through various creative processes and pursuits without fear." (Anthology of young poets' writings, 2000) Here, the result of the poet's research, the power of his gift comes to the forefront. If in his The Moon poem the poet says:

When the Moon was full, my heart just gave a sigh (Anthology of young poets' writings, 2000), -

in another writing he claims as follows:

When the Moon was full, into mischief I ran,

Grieving is my heart, and I was left alone.

See it from the waves on the full Moon,

I am breathing fire into air. (Anthology of young poets' writings, 2000) -

and, through these verses he expresses the mood of his lyrical character. Likewise, such natural phenomena as night, star and seasons are unique attributes of imagination special to the poet's style.

The poet's work entitled Zhas Zhuar (Note 4) was written entirely using the personification method. Through its expressive-emotional meaning, the expression "yearning look" shows the man's affection of the sky realm and the stars. The poet who desires to turn into a star in the sky, expresses his inner feelings and his heart full of dolour by the word "flaring" in the following lines, and continues by comparing his rejoice, admiration to the "buried laughter."

The down casting ephemera of the life, impermanence of the beautiful moments of nature are the motive of the above poem. When we look a bit deeper into the poem's substance, we can see the thrillingly depicted image of the star and its behaviour.

Yearningly watching the Pleiades...

(I wish that I'd be one of them!)

My flaring soul is full of grief,

And my laughter has dug itself (Anthology of young poets' writings, 2000) 


\section{Conclusion}

The foundation of the mankind's being is based on the nature. The man and nature is the target of all art works. Especially in mysterious songs the nature's every single feature is recited in various forms and turned into unique art image. The vivid example of that are Ai (Moon) and Zhuldyz (Star) which gained the status of images in contemporary lyrics of our young poets' poetry. The myths about sky and celestial bodies entered many poetical texts and caused the appearance of new type of images and gained scientific meaning.

First of all the mankind studies the nature, the initial feature that nation taught a man is a cognitive skill. The poetry develops according to each nation's concept, being and the way of life. Initially the concept that the nature is a live spirit made people think that they can speak with it, but eventually this concept served a significant role in the system of artistic thinking. The nature in contemporary Kazakh poetry is in the period of flourishing. The description of nature by thorough comparison of the mankind's being through the prism of consciousness, representation of the man's bad and good traits and delivering it on the level of personality is well developed in the contemporary Kazakh poetry.

In this article we can see that the devices which are used to make abstract concepts materialized, inanimate concepts animate and even abstract things animate are widely used in the contemporary Kazakh poetry. All these makes clear that the new and complex language is emerging.

In conclusion it becomes clear that the lyrics of nature described the phenomena of inner world of a man through psychological parallelism. The novelties in works of the poets of independence period were researched from artistic prospective, and the examples peculiar to the lyrical poems of poets were defined and analyzed as artistic devices formed in contemporary poetry.

\section{References}

Akhmetov, Z. (2002). Olen sozdin patshasy (The Peak of Poetry Is Wisdom). Astana: Foliant

Antologiasi, Z. A. (2000). Anthology of young poets'writings. Almaty: Olke

Askerbekqyzy, Z. (2001). Qarakoz- Kuz (Qarakoz-Spring). Astana: Elorda

Askerbekqyzy, Z. (2008). Korkemdik Orys (Scope of Imagination). Almaty: Zhalyn

Issadil, A. (2012). Kokzhiyekke singen zhol (A road towards horizon). Almaty: Zhalyn

Orhon Zhazbalary. Kultegin. Tonikok. (2001). (Orhon Monuments. Kultegin. Tonikok). Almaty: Atlas

Qasqabassov, S. (1984). Qazaqtin halyq prozasi (The Kazakh Folk Prose). Almaty: Gilym

Raiymbekuly, M. (2001). Ai (The Moon). Almaty: Zhazushy

Sarybai, B. (2007). Aina (Mirror). Almaty: Zhalyn

Temirbai, A. (2008). Min bir mun (A Thousand and One Sorrows). Almaty: Zhalyn

\section{Notes}

Note 1. Senior wife in polygamy.

Note 2. Destiny.

Note 3. An old man (literally "white beard").

Note 4. Tear Washer.

\section{Copyrights}

Copyright for this article is retained by the author(s), with first publication rights granted to the journal.

This is an open-access article distributed under the terms and conditions of the Creative Commons Attribution license (http://creativecommons.org/licenses/by/3.0/). 